\title{
FOTOGRAFÍA, TURISMO E IDENTIDAD NACIONAL EN EL PRIMER FRANQUISMO (1939-1959): RAFAEL CALLEJA Y LA APOLOGÍA TURÍSTICA DE ESPAÑA
}

\author{
María Ramón Gabriel \\ Jacobo García Álvarez. \\ Universidad Carlos III de Madrid
}

\section{RESUMEN}

Este trabajo se centra en el análisis de una obra de gran interés para entender la política turística del primer franquismo (1939-1959): Apología turística de España. Publicada en 1943 por la Dirección General de Turismo, fue editada y prologada por Rafael Calleja, en aquel entonces jefe de la Sección de Propaganda y Publicaciones del citado organismo, y contiene una selección de 439 fotografías de paisajes, monumentos y escenas y tipos humanos de las distintas regiones históricas españolas. Como se intenta mostrar en este artículo, esta obra compendia algunas de las claves principales del discurso turístico oficial del régimen, así como de su concepción de la identidad nacional española.

Palabras clave: España; política turística; imagen turística; propaganda; franquismo; Rafael Calleja; fotografía; paisaje; identidad nacional.

Photography, tourism and national identity in the First Francoism (1939-1959): Rafael Calleja and the Apología Turística de España

\section{ABSTRACT}

This paper focuses on the analysis of a very important book in order to understand the Spanish tourist policy under the first Francoism (1939-1959), namely Apología turística de España. This work, published in 1943 by the Spanish State Tourist Department, was edited

Recibido: 20 de febrero de 2015

Devuelto para su revisión: 4 de junio de 2015

Aceptado: 24 de septiembre de 2015

Departamento de Humanidades: Historia, Geografía y Arte. Universidad Carlos III de Madrid. Campus de Getafe.Calle Madrid, 126.28903 Getafe.MADRID (España).E-mail: mramon@hum.uc3m.es,jgalvare@hum.uc3m.es 
and prologued by Rafael Calleja, who was in charge of the Publications and Publicity Section of this Department, and includes a selection of 439 photos of landscapes, monuments and human scenes and types representing the different Spanish historical regions. As this article will show, Calleja's book summarizes and illustrates in exemplary fashion some of the main keys to the official tourist discourse under Franco's regime and Spanish national identity conception.

Keywords: Spain; tourism policy; tourist image; propaganda; Francoism; Rafael Calleja; photography; landscape; national identity.

\section{INTRODUCCIÓN Y ESTADO DE LA CUESTIÓN}

A lo largo de los últimos veinte años, diversas investigaciones han indagado en la utilización del turismo como un instrumento de propaganda al servicio del régimen franquista (Poutet, 1995; Holguin, 2005; Moreno, 2007; Correyero y Cal, 2008; Pack, 2009, entre otros). La Guerra Civil de 1936-1939 y el complicado contexto de la postguerra española y de la II Guerra Mundial, así como el ostracismo internacional de la dictadura en los años siguientes a esta última, supusieron la paralización de los flujos turísticos internos y externos, y las iniciativas oficiales en el ámbito turístico constituyeron, más bien, «gestos de esperanza» (Pack, ibíd.: 67-68). Durante los años de la Guerra Civil y los primeros de la década de 1940, la afluencia de turistas extranjeros a España cayó a mínimos históricos desde que se poseen estadísticas fiables (apenas 19.000 turistas en 1940) y no recuperó los niveles de los primeros años de la década de 1930 (0,2 millones de llegadas anuales en el período 1931-34) hasta el final de los años 40, en que inició un significativo despegue (0,47 millones de turistas extranjeros en 1950; algo más de 2 millones en 1957; 4,3 millones en 1960), previo al boom de los años 60 (Vallejo, 2011). La situación política posterior a 1936 propició además la utilización del turismo con fines propagandísticos, que fue patente ya en tiempos de la guerra tanto desde el bando republicano como desde el sublevado. Durante los primeros años del régimen franquista, aunque también en décadas posteriores, la promoción turística oficial sirvió en buena medida para dar una imagen de normalidad al país que facilitara, a la vez que la atracción de divisas, la aceptación y el reconocimiento internacional de la dictadura.

En relación con este contexto, el presente artículo pretende resaltar y analizar una obra significativa de aquellos años y a la que se ha prestado poca atención hasta el momento: Apología turística de España (en adelante ATE), concebida en el seno de la administración turística de los primeros años del franquismo y publicada en 1943. Esta obra tuvo una segunda edición en 1957, titulada Nueva apología turística de España (en adelante NATE) y realizada con los mismos objetivos. Ambas fueron impulsadas y preparadas por Rafael Calleja Gutiérrez, quien fue jefe de la Sección de Propaganda y Publicaciones de la Dirección General de Turismo (en adelante DGT) desde 1939 hasta su fallecimiento en 1957.

Aunque algunos estudios dedicados a las dimensiones políticas y propagandísticas del turismo durante el régimen franquista se han referido a $A T E$ y a la figura de Rafael Calleja (Correyero y Cal, 2008; Vega, 2008-2009; Pack, 2009), ninguno de ellos ha ahondado en 
el análisis de esta obra ni en el de las contribuciones de dicha figura a la definición de la imagen turística del país transmitida por la dictadura. Probablemente sea Carmelo Vega el autor que más se ha detenido a analizar $A T E$, dentro de sus estudios sobre la relación entre fotografía y turismo. De la segunda edición, NATE, las referencias son prácticamente inexistentes. Asimismo, el nombre de Rafael Calleja solo aparece mencionado de forma puntual en estos estudios. Pese a ello, su figura nos parece digna de destacar, pues contribuyó sobremanera a la creación y difusión del discurso turístico oficial de su época, así como a apuntalar el conocido lema «Spain is different», que se convertirá durante muchos años en el eslogan principal de la política turística del país.

Por otra parte, la vinculación entre fotografía y turismo ha suscitado interesantes estudios en los últimos años (Robinson y Picard, 2009; Vega, 2011; Donaire, 2012: 179-187; García Álvarez, Puente y Trillo, 2013). La fotografía constituye un medio esencial en la creación de la imagen turística de los destinos, fundamentalmente por ser un instrumento eficaz para transmitir ideas y por su función demostrativa de la realidad, aunque tampoco hay que olvidar que la fotografía turística de carácter institucional (lo mismo que la efectuada con fines comerciales) está, en muchos aspectos, cuidadosamente seleccionada y manipulada. La apariencia de veracidad de la fotografía permite emplearla como un poderoso instrumento de promoción turística. Plenamente consciente de esta capacidad, la DGT utilizó abundantemente las fotografías para sus publicaciones, incluyendo folletos, carteles y obras de carácter monográfico, entre las cuales ATE y NATE son, sin duda, las que más número de imágenes fotográficas contienen. Por ello, el artículo dedicará una atención especial al análisis del material fotográfico de las obras de Calleja, a su importancia en la conformación del discurso turístico oficial del primer franquismo (algunas de cuyas claves se prolongaron hasta los últimos años del régimen) y a la conexión del mismo con la visión de la identidad nacional característica de esta etapa política.

El desarrollo del turismo y la evolución de las concepciones sobre la identidad nacional en España han sido procesos estrechamente relacionados (Afinoguénova, 2007; Storm, 2013). Esta conexión se puede apreciar en determinados discursos e imaginarios, con variaciones más o menos significativas según la época y los intereses de los promotores artífices de los mismos. En el caso que nos ocupa, el discurso turístico oficial de la DGT estaba construido a partir de un imaginario vinculado en buena medida a una visión de la identidad nacional promovida por el régimen franquista y a la tesis de la diferencia española.

Dentro de este discurso e imaginario, el artículo llamará la atención sobre la importancia que, junto a los elementos folklóricos e histórico-artísticos, desempeñaron los de tipo paisajístico. Como es sabido, en determinados discursos e imaginarios sobre la identidad nacional española la apelación al paisaje y el uso de argumentos paisajísticos han jugado un papel fundamental (Ortega, 2005; García Álvarez, 2009; Ortega y Martínez, 2009; Martínez de Pisón, 2012). Asimismo, y en conexión en buena medida con estos argumentos, el paisaje ha sido utilizado a menudo, tanto dentro como fuera de España, en la conformación y la promoción de una determinada imagen del país o de sus regiones (Bertho-Lavenir, 1999; Martín, 2003; Walter, 2004; Roma, 2009; Lois et al., 2010; García Álvarez y Marías, 2011). Las imágenes y argumentos paisajísticos tuvieron también un papel relevante en los inicios de la política turística española, en especial durante la etapa 
de actuación de la Comisaría Regia de Turismo (1911-1928), marcada fuertemente por la figura del marqués de la Vega Inclán y las conexiones de éste con el institucionismo (García Álvarez, 2007; Ortega, 2014).

Al margen de esta introducción y de las conclusiones y bibliografía finales, el presente artículo se compone de cuatro apartados principales, en los que se abordan, sucesivamente, la biografía de Rafael Calleja, atendiendo, sobre todo, a su labor en la administración turística durante la Guerra Civil y el primer franquismo; las características editoriales de las dos obras citadas; el contenido del preámbulo de las mismas y su relación con el discurso turístico del momento (con especial atención a la idea de la diferencia española); y, por último, el análisis del material fotográfico de ambas publicaciones, así como su relación con las concepciones de la identidad nacional características de la dictadura.

Aparte de las fuentes gráficas y bibliográficas publicadas, la investigación que aquí presentamos ha incluido la consulta de documentación de archivo inédita (en especial en el Archivo General de la Administración, en adelante AGA, donde se conservan los expedientes personales de Rafael Calleja y los institucionales de los organismos turísticos para los que trabajó este autor).

\section{RAFAEL CALLEJA Y LA ADMINISTRACIÓN TURÍSTICA ESPAÑOLA DURANTE LA GUERRA CIVIL Y EL PRIMER FRANQUISMO}

\subsection{La administración turística española en el período 1936-1959}

Aunque iniciada durante el reinado de Alfonso XIII, la labor más conocida de Rafael Calleja en la administración turística, y, dentro de ella, la publicación de ATE, se enmarcan directa e ineludiblemente en el peculiar contexto político marcado por la Guerra Civil y los primeros años del franquismo, época en que el turismo fue en gran medida concebido como un instrumento propagandístico. Ya durante el conflicto bélico, los organismos turísticos existentes en uno y otro bando se encargaron de desarrollar diversas actuaciones propagandísticas contra el enemigo. El gobierno de la II República integró el Patronato Nacional de Turismo (PNT) dentro de sus servicios de propaganda y se encargó de la edición de varios carteles y folletos que reivindicaban la protección del patrimonio monumental español frente a las operaciones bélicas acometidas por el bando contrario, aparte de otras iniciativas en el exterior (Instituto de Estudios Turísticos, 2006: 33-39; Moreno, 2007: 137-141 y Correyero y Cal, 2008: 230-237). El bando sublevado, por su parte, creó tanto el Servicio Nacional de Propaganda como el Servicio Nacional de Turismo (SNT), aunque este último organismo hubo de servir en buena medida a los objetivos del primero (Moreno, op. cit. 142-152)1 . La jefatura del SNT recayó en Luis Antonio Bolín y Bidwell (1894-1969), periodista malagueño que había trabajado para el PNT y que habría de ejercer una influencia fundamental en materia turística durante la posguerra. Suya fue la iniciativa de crear las llamadas Rutas de Guerra, posteriormente reconvertidas en Rutas Nacionales de España, unos circuitos organizados en autobús para

1 El SNT estuvo adscrito al Ministerio del Interior cuando se creó en enero de 1938 y, posteriormente, en diciembre de ese mismo año, a la Subsecretaría de Prensa y Propaganda del Ministerio de la Gobernación. 
los turistas extranjeros, que recorrían los lugares conquistados por el bando sublevado (Bolín, 1969: 229-233; Correyero y Cal, 2008: 247-292; Holguin, 2005). En opinión de la historiadora Ana Moreno, Bolín fue «el verdadero traductor al turismo del ideario del primer franquismo» y quien consiguió, de alguna manera, mantener viva la llama del turismo en aquellos difíciles años para el sector (Moreno, 2007: 221).

Después de la victoria del bando franquista en la Guerra Civil, y una vez se produjo la reorganización del gobierno, el turismo continuó formando parte de las actuaciones propagandísticas del Estado. El 8 de agosto de 1939 el SNT se reconvirtió en la DGT, adscrita, significativamente, a la Subsecretaría de Prensa y Propaganda del Ministerio de Gobernación, a imitación de lo que ocurría con el servicio de Turismo de la Alemania nazi. Al frente de la DGT se mantuvo asimismo Luis Bolín, hasta que en junio de 1952 éste fue cesado y sustituido por Mariano Urzaiz y Silva, Duque de Luna. Un año antes, en julio de 1951, la DGT había pasado a integrarse en el recién creado Ministerio de Información y Turismo (MIT), cuyo primer titular sería Gabriel Arias Salgado. Luis Bolín, que nunca dejó de ser, en opinión de Ana Moreno, «un propagandista nato», convirtió la DGT en un organismo de gestión turística y comenzó la dinamización del sector, en unos años marcados por la posguerra, la Segunda Guerra Mundial y el bloqueo internacional al régimen de Franco (Moreno, 2007: 159, Pack, 2009: 67-68).

Como se ha mencionado ya, la Guerra Civil española y la Segunda Guerra Mundial interrumpieron casi por completo la llegada de turistas extranjeros, hasta que a mediados de los años 50 se inició la reconversión del sector, que pasó de ser una actividad vinculada a las élites a transformarse en un fenómeno de masas. De forma muy sucinta, cabe decir que la política turística que se aplicó en la década de 1940 estuvo muy condicionada por la situación económica que atravesaba el país, la autarquía y el intervencionismo del Estado, que ahogaban la iniciativa privada. Por su parte, la década siguiente se caracterizó por el fin del aislamiento económico y político del país, el paulatino abandono del sistema autárquico y un notorio crecimiento del número de turistas extranjeros (Pellejero, 2002: 246).

\subsection{Rafael Calleja (1888-1957): semblanza biográfica}

Rafael Calleja Gutiérrez (Madrid, 24 de marzo de 1888 - íd., 24 de octubre de 1957) fue el hijo mayor del famoso editor Saturnino Calleja Fernández (1855-1915), fundador de la Editorial Calleja (Ruiz Berrio et al., 2000; Fernández de Córdoba, 2006). Estudió Derecho en Madrid y conectó desde joven con el ambiente cultural de la capital al formar parte, junto a su amigo Salvador Bartolozzi, de la tertulia literaria de Ramón Gómez de la Serna en el Café Pombo. Aparte de ser escritor desde temprana edad, la vida profesional de Rafael Calleja se divide esencialmente en dos etapas: la primera, comprendida aproximadamente entre 1915 y 1930, como presidente de la Editorial Calleja; y la segunda, desde 1930 hasta su fallecimiento, como publicista del turismo español para el PNT, el SNT y la DGT.

La primera de estas dos etapas se inicia cuando, tras la muerte de su padre, se hace cargo de la dirección de la Editorial Calleja, ubicada en San Sebastián, con la que ya colaboraba desde hacía algún tiempo, sobre todo a raíz de la enfermedad de Saturnino 
Calleja. Continuando la línea editorial de su padre, la amplió a la literatura y las obras científicas y renovó las técnicas y el estilo, creando nuevas colecciones y propiciando un notorio crecimiento de la editorial. El acta de acciones de 6 de junio de 1931 es la primera en la que no aparece como presidente, por lo que debió de dejar la editorial por esta fecha (Fernández de Córdoba, ibíd.).

Coincidiendo con sus últimos años como presidente de la editorial familiar, Rafael Calleja comenzó a trabajar como publicista del turismo oficial, labor en la que, con excepción de los primeros dos años de la Guerra Civil, permanecería el resto de su vida². Así, el 16 de octubre de 1929 ingresó en la plantilla del PNT como funcionario de la Sección de Propaganda y Publicaciones y, unos meses después, decidió trasladarse a Madrid. El 3 de diciembre de 1931 se le nombró Secretario General del PNT, como Jefe de Administración de tercera clase de su cuerpo técnico administrativo. Asimismo, se le designó para realizar un estudio en París y Berlín sobre un plan de propaganda del turismo español (Gaceta de Madrid de 15 de junio de 1932).

El 4 de agosto de 1936 finalizó su trabajó en el PNT al ser cesado de su puesto por mostrarse desleal al gobierno de la II República tras el estallido de la Guerra Civil (Gaceta de Madrid de 5 de agosto de 1936). Desde septiembre de 1936 hasta marzo de 1937 estuvo refugiado en la Embajada de México en Madrid, mientras que su familia se trasladó a Burgos. A partir de marzo de 1937 comenzó a trabajar como funcionario para el SNT, trasladando de nuevo su residencia a San Sebastián. Según se recoge en la correspondencia personal de Calleja conservada en el AGA, el 21 de junio de 1938 Luis Bolín, desde sus oficinas instaladas provisionalmente en Burgos, le rogó su incorporación inmediata al SNT como jefe de la Sección de Propaganda y Publicaciones, designación en la que seguramente pesaron tanto su experiencia en el PNT como su trayectoria previa al frente de la célebre editorial familiar. El 6 de mayo de 1939, apenas un mes después del final de la Guerra, Luis Bolín instó a Rafael Calleja a dejar su residencia en San Sebastián y trasladarse a Madrid de forma permanente para organizar la Sección de Propaganda y Publicaciones del SNT, cuyas oficinas centrales se montaron en la calle Duque de Medinaceli, $\mathrm{n}^{\circ} 2$, el mismo local que previamente había albergado la sede de las oficinas del PNT. El interés de Bolín por impulsar la labor de dicha sección y analizar el copioso archivo fotográfico hallado por el bando vencedor de la guerra en las antiguas oficinas del PNT aceleraron el traslado a la capital de Calleja, quien, con la reconversión del SNT en la DGT, fue nombrado, el 13 de octubre de 1939, Jefe de Administración de tercera clase de la Sección de Propaganda y Publicaciones de la DGT. Durante su etapa en la DGT, Rafael Calleja fue ascendido por antigüedad tres veces ${ }^{3} \mathrm{y}$ en varias ocasiones llegó a sustituir de facto a Bolín al frente de dicho organismo, durante breves períodos en que este último se

2 Las noticias siguientes referidas a las funciones desempeñadas por Rafael Calleja en la administración turística española se apoyan en su expediente personal, consultado en el AGA, Sección Cultura, Expediente $42 / 4821$.

3 El 1 de enero de 1942, se le asciende a jefe de Administración de segunda clase del cuerpo técnico administrativo de la DGT, con sueldo anual de 13.200 pesetas. El 2 de enero de 1945, se le asciende a jefe de Administración de primera clase, con sueldo anual de 16.400 pesetas. Por último, asciende a jefe Superior de Administración Civil del cuerpo técnico administrativo de la DGT con efectividad a partir del 1 de enero de 1949, con sueldo anual de 17.500 pesetas (AGA, expediente citado). 
ausentó ${ }^{4}$. Pese al cese de Bolín en la DGT, Rafael Calleja continuó desempeñando su cargo como Jefe Superior de Administración Civil del MIT y en 1952 participó activamente en la redacción del Anteproyecto del Plan Nacional de Turismo. Falleció en Madrid el 24 de octubre de 1957, tras cerca de veintiocho años de servicio prácticamente ininterrumpido en la sección de propaganda y publicaciones de la administración turística del Estado. $\mathrm{Su}$ labor en dicho campo fue glosada y resaltada por Melchor Fernández Almagro en una elogiosa reseña publicada en el diario $A B C$ con ocasión del primer aniversario de su muerte (Fernández Almagro, 1958).

Las principales publicaciones de temática turística preparadas por Rafael Calleja fueron tres, todas de similar estructura y publicadas por la Dirección General de Turismo: ATE, NATE y otra de menor relevancia titulada Granada: 461 grabados, fotografias y dibujos, de la que se desconoce su fecha exacta de publicación (Calleja, s.a.). Asimismo, escribió diversas colaboraciones en la revista Hospes ${ }^{5}$.

\section{CARACTERÍSTICAS EDITORIALES DE ATE Y NATE}

ATE fue publicada en 1943 por la Sección de Propaganda y Publicaciones de la DGT, un organismo comandado por Luis Bolín y adscrito por aquel entonces, como ya se ha indicado, al Ministerio de la Gobernación. Fue uno de los primeros libros de temática turística general publicados en España tras la Guerra Civil y durante la Segunda Guerra Mundial. La obra, de un total de 283 páginas, contiene 439 fotografías de paisajes, monumentos y aspectos típicos de España, distribuidas en 224 páginas. Se trata, por tanto, de un libro de contenido eminentemente fotográfico. Las fotografías van precedidas de un preámbulo de 40 páginas redactado por Rafael Calleja e ilustrado por 40 dibujos de Serny ${ }^{6}$ en que se describen sumariamente y ensalzan los principales atractivos turísticos de España. Además de la redacción del texto, Rafael Calleja fue el responsable de la selección y compilación de las fotografías y de la dirección artística de la edición. Del huecograbado y el fotograbado de la obra se encargó la empresa Arte Bilbao, y de la tipografía y la encuadernación Artes Gráficas Faure de Madrid. Se publicaron 4.000 ejemplares de ATE, de los cuales 2.000 se pusieron a la venta y 2.000 fueron repartidos de forma gratuita, con el objetivo último de que el libro sirviera de indirecta pero eficaz propaganda. El coste total de la edición de ATE fue de 108.982,50 pesetas, más 200 pesetas abonadas a Serny por sus dibujos del preámbulo, que fueron especialmente diseñados para la obra. A Rafael Calleja no se le pagaron derechos de autor ni el trabajo de la dirección artística. El producto neto de los ejemplares vendidos fue de 197.166 pesetas, por lo que ATE produjo beneficios, en concreto de 86.183,50 pesetas, que fueron destinados al Tesoro Público. Los ejemplares vendidos se agotaron rápidamente $\mathrm{y}$, aunque se recibieron encargos pos-

4 Por ejemplo, el 13 de noviembre de 1939, el 3 de agosto de 1940 (hasta fines de septiembre) y el 22 de julio de 1941 (AGA, expediente citado).

5 Hospes era una revista mensual, de 46 páginas, del Sindicato Nacional de Hostelería y Similares, que estaba patrocinada por la DGT y cuyo director era Luis Bolín. La revista apareció en mayo de 1942, y se editó aproximadamente hasta 1950, cuando se empezó a publicar la revista Hostal (Correyero y Cal, 2008: 303-306).

6 Serny (Ricardo Summers Ysern), nacido en Puerto de Santa María en 1908 y fallecido, en Madrid en 1995, fue un artista español destacado. Dentro de su obra relacionada con el turismo, es autor de los dibujos de los preámbulos de ATE y NATE y de los dibujos de algunos carteles turísticos de la época. 
teriores durante bastante tiempo, estos no pudieron servirse. Algunos años después de la publicación, Rafael Calleja se congratulaba en un documento interno del éxito del libro, que a su juicio había sido «resonante» y había inspirado la publicación de otras obras de temática y propósito similar:

«Se publicaron en España y fuera de España críticas tan elogiosas como abundantes y el libro, en el que se hizo con fortuna la apología turística de España a que el título se refiere, fue leído, admirado y conservado en proporción al éxito obtenido. Se consiguió así una propaganda de España de excepcional intensidad y de calidad relevante. Y, según queda mencionado, esa grande y eficaz propaganda fue, no ya económica, no ya gratuita, sino lucrativa para el Estado» ${ }^{7}$.

Aunque publicadas en momentos distintos para el desarrollo del turismo español, ATE, y también su posterior edición, NATE, fueron recibidas con entusiasmo por la prensa de la época, que también alabó la gestión de Luis Bolín y el trabajo de Rafael Calleja ${ }^{8}$. La primera fue entendida, sobre todo, como una obra propagandística y de invitación a la espera de la llegada del turismo extranjero a España una vez finalizara la Segunda Guerra Mundial, y que sintetizaba las posibilidades turísticas del país a través de las fotografías de paisajes, tipos y monumentos (Correyero y Cal, op. cit.: 413-415). La segunda fue enjuiciada muy positivamente por Melchor Fernández Almagro, que destacaba «la pluma expertísima [de Calleja] en el conocimiento de diversas disciplinas y en su expresión literaria», así como el patriotismo que la inspiraba y «el cuantioso y rico apresto gráfico que le da a la obra precioso contenido» (Fernández Almagro, 1959).

NATE fue publicada en 1957, catorce años después de $A T E$, también por la Sección de Propaganda y Publicaciones de la DGT, organismo adscrito al MIT desde 1951. De hecho, esta segunda edición ya estaba planeada por Rafael Calleja, al menos, desde el año 1954, pero la escasez de fondos de la DGT y el encarecido coste que suponía obligaron a posponer la publicación ${ }^{9}$. Durante 1956 se preparó definitivamente la reproducción de ejemplares, que se finalizó al año siguiente. La idea de Rafael Calleja era presentar una nueva edición que contuviera «las enseñanzas obtenidas» en ATE y las transformaciones del país y del sector turístico operadas desde la publicación de la primera de las dos obras. Así, planteó una reimpresión de mayor calidad que la primera (dibujos en color, mejor papel, mayor tamaño, mayor número de fotografías, láminas a color, dos tipos de encuadernación...) y estimó que el procedimiento del concurso, mediante el que se publicaban el resto de obras de la DGT, no convenía para la edición de calidad que estaba preparando. Por ello, solicitó un crédito a justificar de 2.500 .000 pesetas para la publicación de $N A T E^{10}$, un libro que él consideraba de lujo y de corte difícil, que conllevaba una labor personal

7 Carta con fecha de 11 de noviembre de 1954, consultada en el AGA, Sección Cultura, Caja 13.020.

8 Las críticas en prensa de las obras pueden encontrarse en Correyero y Cal (2008: 414-415) y en las hemerotecas digitales de $A B C$ y La Vanguardia.

9 Según consta en una carta escrita por él, con fecha de 11 de noviembre de 1954 encontrada en el AGA, Sección Cultura, Caja 13.020.

10 El 13 de diciembre de 1955 Rafael Calleja solicita la cantidad citada, que fue aprobada por expediente T.2/56 de la DGT (AGA, Sección Cultura, Caja 13.020). 
delicada y minuciosa y cuyos detalles se irían planteando a medida que se hacía. Además, propuso aumentar el número de ejemplares publicados a 10.000, 6.000 más de los que compusieron la tirada de $A T E$. De ellos, 8.000 irían destinados a la venta y 2.000 a la distribución gratuita. La posibilidad de disponer de crédito ilimitado para la publicación era, según Calleja, un requisito sine qua non para el cumplimiento de los objetivos propuestos con la edición de $N A T E$, con la que Calleja preveía superar el éxito obtenido con ATE y llevar a cabo «una propaganda extraordinaria».

De las tres casas editoriales que se barajaron para la edición de $N A T E^{11}$, fue elegida Heraclio Fournier al considerarse que contaba con los elementos más adecuados para realizarla con la calidad que se requería. De los expedientes relativos a la edición de NATE, conservados en el $\mathrm{AGA}^{12}$, se deduce que ésta ocasionó gastos por un importe total de 2.376.042,50 pesetas, con cargo al crédito concedido para tal fin, sin contar los estuches que se encargaron posteriormente para guardar los ejemplares editados.

Esta nueva edición, en la que Rafael Calleja vuelve a ser responsable de la dirección artística, la selección fotográfica, la composición y el texto del preámbulo, conserva la misma estructura que $A T E$, aunque añade a ella apartados nuevos. De mayor formato y extensión que su predecesora $(33$ x $27 \mathrm{~cm}$ y 585 páginas, frente a los 30 x $21 \mathrm{~cm}$ y 284 páginas de $A T E), N A T E$ contiene un preámbulo de 31 páginas, ilustrado con 32 dibujos de Serny a color y seguido por un dosier de 484 fotografías en blanco y negro, tras el que se añaden un dosier de 65 láminas a color (en su amplia mayoría fotográficas), la traducción del preámbulo al inglés, francés y alemán, y una amplia reseña en castellano, inglés, francés y alemán de las fotografías a blanco y negro y de las láminas en colores, redactada por José Manuel Pita Andrade, profesor de Historia del Arte de la Universidad de Madrid.

Para la redacción del preámbulo de NATE, Rafael Calleja toma como base el preámbulo de $A T E$. Las páginas del preámbulo en castellano presentan el texto acompañado del título de la obra en mayúsculas decorativas naranjas y, en las esquinas laterales, de los dibujos de Serny a color y con títulos solo en castellano. Aunque en apariencia pueda parecer que se trata del mismo texto que el preámbulo de $A T E$, el autor introduce en NATE algunas modificaciones relevantes, aportando no sólo informaciones geográficas y culturales más amplias y concretas que las de la obra anterior sobre las distintas regiones españolas y sus principales atractivos patrimoniales (paisajes, monumentos, costumbres y fiestas típicas), sino también detalles sobre otras actividades turísticas que se podían realizar en la época (caza y pesca, esquí, golf, etc.), así como las referidas a alojamientos y medios de transporte (en particular sobre la red de paradores y albergues de la DGT) (Calleja, 1957: 11-12). Las reflexiones del preámbulo de ATE relativas a los fundamentos de la diferencia española y a los procesos homogeneizadores introducidos por la vida moderna que amenazan con diluirla, a las que nos referiremos en el siguiente apartado, desaparecen, de manera significativa, en el preámbulo de $N A T E$. Estas diferencias hacen que el preámbulo de $N A T E$, aun apoyándose también en el valor literario del texto, se asemeje mucho más que su predecesora a una suerte de guía turística sintética del país.

11 Heraclio Fournier S.A. de Vitoria; Seix Barral Hermanos; y S.A. D. A. G., estas dos últimas sitas en Barcelona.

12 Un total de 13 expedientes localizados en la Sección Cultura, Cajas 13.010, 13.017, 13.018 y 13.020. 


\section{SOBRE EL PREÁMBULO DE ATE Y EL DISCURSO TURÍSTICO DEL PRI- MER FRANQUISMO. ORIGEN, SIGNIFICADO Y CONTINUIDAD DEL «SPAIN IS DIFFERENT»}

El contenido del preámbulo de ATE se desarrolla bajo la premisa de que las características diferenciales de España son sus mejores atractivos turísticos, una idea que se encuentra en la base del conocido eslogan turístico «Spain is different». El texto, que ha sido valorado por algunos autores como «un auténtico panegírico sobre el ser español y su idiosincrasia» (Correyero y Cal, 2008: 415), se apoya fundamentalmente en dos ideas: el elogio de la diversidad regional de España, con la riqueza de recursos turísticos que ella comporta, y la identificación de aquellos rasgos que permiten diferenciar el país del resto de Europa. Para Calleja, la primera de esas ideas se expresa sobre todo en la variedad paisajística y folklórica. Si desde el punto de vista geográfico «ese pueblo [el español] bien puede jactarse de reunir, en espacio relativamente estrecho, las más rica y matizada variedad de los paisajes europeos» (Calleja, 1943: 7), desde el de las fiestas y tradiciones populares, «esta opulencia de personalidad, diversificada en las variantes propias de cada región, da un resultado folklórico excepcional, y está en la base misma de la atracción singular que España ejerce sobre los extranjeros» (ibíd.: 10). Para el autor, España es un país caracterizado por su contraste de norte a sur, a la medida de todos los gustos, donde se goza, además, de buen clima y de «la sencilla y acogedora llaneza (...) idiosincrásica de los españoles» (ibíd.: 24). Idea sobre la que se explaya en el pequeño texto que cierra la obra y que acompaña la última fotografía expuesta en ella:

«Paisajes cenceños, amables panoramas, montes, llanuras, acantilados hoscos, playas apacibles, huellas de todos los siglos, brisas y flores de todos los climas: tan rico es el caudal de nuestras bellezas naturales, monumentales, pintorescas, tan multiforme la diversidad de lo típico peculiar, que inventariar tan espléndida abundancia sólo pensaría intentarlo quien no conozca su opulencia innumerable. Por ello en las páginas precedentes apenas se pretende sugerir cómo se encierran en este relicario de Arte, de Historia y de Naturaleza que es nuestra España, inagotables tesoros envueltos en todas las luces, desde el suave gris sedante de las tierras blandas, al brillo fulgente de las encendidas por nuestro sol, cuya alegre caricia es privilegio destacado» (ibíd.: 224).

La segunda de las ideas esenciales del preámbulo de $A T E$ es la de que, «a pesar de la estandarización ingrata (...) entre los valores turísticos de España guardamos aún filones pomposos de ese noble metal: lo diferente» (ibíd.: 33). Entre esos valores figura, por supuesto, la diversidad geográfica y cultural a la que antes se aludió, y el propio texto de Calleja consiste principalmente en un recorrido, escrito en tono literario, por las «bellezas naturales, monumentales, pintorescas» (ibíd.: 224) de las distintas regiones españolas. Pero, más allá de esa diversidad, Calleja se afana en destacar que es «el factor humano», «la preeminencia del carácter», y en particular «la nota oriental», derivada de la huella musulmana, lo que unifica y define más decisivamente la personalidad del país y su valor turístico «diferente»: 
«La nota oriental es una de las más peculiares en España, y de ella están empapados sus caracteres más típicos y personales. Una compenetración de siglos con los musulmanes dejó en la tierra y en el alma españolas huellas bien visibles, que bastarían a distinguir de los demás europeos a este país por esencia diferente» (ibíd.: 12).

Y ello explica también, según afirmará más adelante Calleja, que «Andalucía es lo más conocido de España en el mundo, hasta ser para muchos extranjeros lo español por antonomasia» (ibíd.: 29). Pero además, para el autor, la diferencia española reposa sobre la abundancia de paisajes, fiestas y costumbres tradicionales y «pintorescos» (palabra que se repite constantemente en el preámbulo), han pervivido hasta entonces porque el país seguía siendo un territorio de población mayoritariamente rural y deficientemente comunicado con el exterior. Para Calleja, son precisamente los procesos de urbanización y los avances en los transportes y comunicaciones los que tienden a igualar cada vez más los paisajes y las experiencias turísticas de España con los de otros países occidentales y a diluir lo diferente y lo genuino de cada pueblo. La preocupación del autor en este sentido se expone particularmente al referirse a la evolución reciente de la capital del país y merece reproducirse en extenso:

«Madrid, hoy irrecuperablemente mejorado, ha perdido su personalidad genuina: de cuando era gran pueblo íntimo, peculiar. Ya es una ciudad grande, y empieza a ser como las otras. Lo cual no es deterioro privativo de nuestro Madrid maravilloso; lo es de la época corrosiva del color local, pulverizadora de lo pintoresco, hostil a lo singularizado. Antes cada pueblo, y señaladamente España, vivía en sí. Libros y viajeros eran limitado y exclusivo medio de transfusión internacional. Arquitectura y folklore eran por doquier una forma más de vegetación autóctona. Hace contados años, viajar significaba descubrir. Cada país era un país; cada ciudad, una ciudad; cada hotel, un hotel. Pero lo diferente, que siempre fue valor preciado, empezó con el siglo a ser precioso; y de escaso como el oro, ha pasado con rapidez a ser tan raro como la esmeralda, y pronto será inusitado y exorbitante, como el radium o la virtud perfecta. La revista ilustrada y luego el cine, el auto y el avión, han empequeñecido y divulgado en demasía este mundo; se acerca el día tremendo en que apenas quede algo nuevo, ni desconocido, ni largo, ni lento, ni recóndito, ni apacible. Cada rincón abrupto del planeta, cada secreto seguro deleitoso, van estando ya tan sobados como sólo lo estaban la Gran Pirámide o la Torre Eiffel [...] Y en cada Palace de cada gran urbe, en vez de aquel recinto personal de los hoteles distintos, con propia fisonomía, nos recibe la misma habitación, el mismo hall alfombrado, idénticos rótulos y el mismo portero, que habla francés con acento alemán, alemán con acento ruso, e inglés o español con acento americano. Si se dice el Plaza, el Astoria, el Majestic, el Ritz, ¿quién sabe si se trata de Roma, de Chicago, de Buenos Aires o de Budapest? Ni el nombre ni los muros tienen nacionalidad. Lo más estricto que se puede decir es que son hoteles del siglo XX» (ibíd.: 31-32).

Teniendo en cuenta el cargo que ocupaba el autor y las obras en que se publicaron, editadas directamente por la administración turística, los textos de Rafael Calleja que acabamos de resumir pueden considerarse, pues, una de las formulaciones «oficiales» 
más tempranas, explícitas y acabadas de la idea de la diferencia española como principal recurso y reclamo turístico del país. Como es conocido, la idea cristalizará pronto en un eslogan que, sin olvidar algún precedente aislado de la época del $\mathrm{PNT}^{13}$, aparece ya en algunos carteles turísticos publicados por la DGT, con el impulso directo de Calleja, a fines de los años 40 y principios de los $50 ;{ }^{14}$ y que sobre todo se popularizará en la década de 1960 a partir de las campañas de promoción turística realizadas durante el mandato de Manuel Fraga Iribarne, Ministro de Información y Turismo entre 1962 y 1969.

Ciertamente, el eslogan conectaba bien con la imagen del país forjada por los viajeros románticos a lo largo del siglo XIX, sobre la cual se irá construyendo, ya desde esa misma época y con distintas variantes, una visión turística de España como un destino escapista y exótico, rico en paisajes naturales, monumentos históricos y personajes típicos y bucólicos (Afinoguénova, 2007). La preocupación por la diferencia y la «anormalidad» e incluso excepcionalidad españolas en el contexto europeo está intensamente presente, asimismo, en los encendidos debates y polémicas sobre la identidad nacional planteados a partir de finales del siglo XIX desde diversas corrientes intelectuales internas (Fusi, 2000). Ciertamente también, el eslogan en cuestión sólo se hará conocido dentro y fuera de España a partir de 1964, cuando el MIT de Fraga lo inserte en pósteres de propaganda dirigidos a conmemorar el XXV aniversario del final de la Guerra Civil (o, según la fórmula oficial utilizada, «los XXV años de paz»), y con la idea de promocionar un programa de renovación económica e ideológica del país por la vía del turismo (Poutet, 1995; Kelly, 2000; Afinoguénova y Martí-Olivella, 2008). El lema «Spain is different», al mismo tiempo que se adaptaba bien al nacionalismo exaltado de la dictadura, se aprovechó, pues, no sólo con la intención de atraer turistas a un destino exótico, con pintorescas costumbres y tradiciones locales que diferían de las pautas europeas, sino también para legitimar ideológica y políticamente el régimen de Franco tanto en el exterior como a nivel interno, vinculándolo a la estabilidad, el orden público y el progreso experimentados por el país desde el inicio del mismo.

Pero con independencia de la popularización y consagración del eslogan durante los años 60, lo que queremos destacar aquí es que la fórmula «Spain is different» ya era fundamental en el imaginario turístico del primer franquismo, tal y como ejemplifica el trabajo llevado a cabo por la Sección de Propaganda y Publicaciones de la DGT bajo el mandato de Rafael Calleja. De hecho, se puede percibir una coherencia entre las diversas publicaciones impulsadas por la DGT en este período, pues, por ejemplo, y como veremos posteriormente, un número considerable de fotografías de ATE y NATE también fueron

13 Afinoguénova $(2007,55-56)$ y Vega $(2008-2009,196)$ han documentado la existencia de una serie de carteles fotográficos con el lema «Spain is different» publicados por la oficina del PNT en París en torno a 1929 ó 1930. Afinoguénova reproduce en su trabajo uno de estos carteles, ilustrado con una fotografía de Andrada que representa a una mujer y a dos hombres vestidos con los trajes típicos lagarteranos. No hay constancia de esta serie en los catálogos del Instituto de Estudios Turísticos (IET), ni en el impreso (IET, 2005), ni en el digital (http://www.iet.tourspain.es, consultado el 27-IX-2013).

14 En 1948 y 1949 se editan carteles fotográficos (varios de ellos obra de Kindel) con el eslogan «Spain is beautiful and 'different. Visit Spain», así como «Spain is beautiful and 'different'. Visit sunny Spain», y en 1950 aparecen nuevos carteles con la segunda fórmula mencionada, así como otros con el eslogan «Spain is 'different'. Visit Spain». El MIT recuperó el eslogan en 1961, en 1962 y, por última vez, en 1964. Todos esos carteles pueden verse en el catálogo digital del antiguo IET, actualmente Subdirección General de Conocimiento y Estudios Turísticos (http://www.iet.tourspain.es/, consultado el 2-II-2015), y, por lo que toca al período anterior a 1960, también en el catálogo publicado por ese mismo organismo (IET, 2005). 
utilizadas en carteles turísticos. Además, las conexiones establecidas entre los argumentos de $A T E$ en torno a las características diferenciales de España y la serie de carteles turísticos producidos por la DGT a partir de 1948 permiten resaltar la importancia de dicha obra dentro del discurso turístico oficial del momento.

Finalmente, cabe significar que el conocido eslogan ha sido entendido y utilizado de diferentes formas, tanto en períodos distintos como dentro del mismo período. En la época franquista, el lema fue explotado sin duda desde una perspectiva política como expresión de los valores nacionales y distintivos de España frente al mundo, pero también lo fue $-\mathrm{y}$ las publicaciones de la DGT durante el primer franquismo constituyen muestras evidentes en ese sentido- en relación con el concepto de belleza (Vega, 2008-2009: 197). En este caso, el eslogan viene a significar que lo diferente de España radica en la abundancia y belleza de recursos turísticos resumidos en torno a la trilogía Naturaleza, Arte e Historia, tal y como se vendía en las campañas de promoción de nuestro país durante los dos primeros decenios de la dictadura e incluso en etapas políticas anteriores. La apelación a esa trilogía figuraba, por ejemplo, en discursos del PNT, en el que, como ya se ha indicado, el propio Calleja inició su trayectoria profesional como publicista ${ }^{15}$. En último término, cabría considerar que el eslogan recogía aspectos de una imagen turística creada por los viajeros románticos por nuestro país en el siglo XIX. «Spain is different» ha sido, y sigue siendo, en definitiva, uno de los eslóganes que más ha pervivido en la memoria, tanto de los españoles como de los extranjeros, al punto de convertirse en una suerte de clave interpretativa de la identidad nacional, y por ende repetida en numerosas caracterizaciones de la sociedad española.

\section{LA IMAGEN DE ESPAÑA EN LAS FOTOGRAFÍAS DE ATE Y NATE}

\subsection{Los autores de las fotografías y su conexión con el cartelismo de la DGT}

El preámbulo de las dos obras analizadas sirve de hilo argumental al amplísimo dosier fotográfico de las mismas, cuyo conjunto ofrece cerca de un millar de imágenes (439 en ATE, 549 en NATE, sumando en el segundo caso las 484 fotos en blanco y negro y las 65 láminas a color, que en su extensa mayoría consisten en fotografías), y que, como ya se ha indicado, resulta de hecho su aspecto más relevante y destacado. Como bien ha señalado Vega,

«más allá del simple panfleto publicitario, este libro $[A T E]$ marcaba ya una línea de actuación que en las décadas siguientes habrían de seguir otras producciones similares, esto es: una edición de calidad sustentada en el valor literario del texto -que trascendía la pura descripción informativa para recrear impresiones, y plasmar opiniones sobre los lugares-, y con un protagonismo absoluto de las imágenes fotográficas» (Vega, 2008-2009: 194).

15 El R.D. de 25 de abril de 1928, creador del PNT, menciona en su exposición de motivos que «España ofrece al viajero, en algunos aspectos como ninguna otra nación, singulares atracciones por la magnificencia de su Arte, la belleza de su territorio y el interés vivísimo de su Historia» (Gaceta de Madrid de 26 de abril de 1928).

Sobre la consideración del paisaje en el PNT, véase Ortega (2014: 40). 
La organización de todas las fotografías de $A T E$ y de las fotos en blanco y negro de NATE se apoya, fundamentalmente, en un criterio geográfico. En ambas obras, el bloque principal del dosier fotográfico se articula por la división en «regiones históricas» característica de la época (esto es, la apoyada en el Real Decreto de 30 de noviembre de 1833), aunque, como es sabido, tal división no tuviera entidad administrativa alguna entonces ni el propio Calleja utilice explícitamente dicha expresión. Las fotos se refieren de hecho a provincias, agrupadas en su práctica totalidad según criterios regionales históricos, en el siguiente orden: Galicia, León, Asturias, Santander, País Vasco, Navarra, Aragón, Cataluña, Baleares, Valencia, Murcia, Castilla la Nueva, Castilla la Vieja, Extremadura, Andalucía y Canarias. Las fotos de este bloque representan esencialmente localidades, paisajes y monumentos, e incluyen imágenes de las 50 provincias españolas. Concluida esta serie de fotografías ordenadas por regiones históricas, en ambas obras el editor añade un último bloque que en el índice de NATE denomina como «tipos». Este bloque final se inicia con fotografías de escenas y tipos humanos (en que se incluyen escenas del mundo rural, atuendos tradicionales, fiestas y danzas, etc.), identificados también por regiones históricas (y en algunos casos por provincias), y termina con imágenes de cultivos y alimentos típicos (tales como plátanos, naranjas, aceitunas, trigo, uvas y maíz), ya sin referencia geográfica concreta, presentados, bien de forma aislada, bien mediante escenas representativas del trabajo agrícola. Por lo que toca al dosier de 65 láminas en color añadido en $N A T E$, no sigue un orden geográfico claro y posee una temática más variada que el dosier en blanco y negro, alternando paisajes, monumentos y escenas y tipos humanos con obras pictóricas de fama internacional (cuatro cuadros del Greco y Velázquez, tres de Goya y uno de Murillo y Ribera), e incluso imágenes de actividades o espacios específicamente orientados al turismo, el ocio y la recreación (playas, parques y jardines urbanos, estaciones de esquí, etc.), y en donde es visible la presencia del turista.

La selección de las fotografías de las obras aquí analizadas, llevada a cabo por Calleja, responde obviamente a la concepción que el autor y la administración para la que trabajaba y que publicó las obras tenían sobre cuáles eran los valores turísticos principales y diferenciales que poseía el país y por tanto debían promocionarse; o dicho de otro modo, al tipo de imagen turística de España que se quería trasmitir, y que se apoyaba, según vimos, en la trilogía formada por el Arte, la Historia y la Naturaleza. Los contenidos de las fotos se centran en el folklore, las costumbres, el patrimonio religioso y castellológico, las ciudades históricas, los ámbitos rurales y los paisajes naturales. En palabras de Vega, «estas fotografías constituían un resumen visual de lo que por entonces se pensaba que España podía ofrecer desde una perspectiva turística, y reforzaban las tesis propagandísticas del autor, contaminadas de patriotismo y del 'orgullo de ser español': la fotografía jugaba aquí una función apologética de primer orden, mostrando al público lo más característico y significativo de nuestro país» (Vega, 2008-2009: 194). Como advertía el propio Calleja en la primera página del dosier fotográfico de $A T E$, «cantan la mejor apología turística de España sus paisajes, sus piedras gloriosas, sus aspectos típicos» (Calleja, 1943).

Asimismo, es importante precisar que, aunque relacionadas con la práctica turística, las fotografías de $A T E$ no muestran espacios específicamente construidos para el consumo turístico, tal y como los entendemos en la actualidad, porque en la fecha de publicación de la obra estos apenas existían en el país. En NATE, pese a enmarcase ya la obra en un contexto 
de despegue del turismo de masas, las fotografías continúan en la línea del discurso turístico de $A T E$, con dos pequeñas salvedades: aparecen más monumentos o edificios emblemáticos civiles, como fachadas y detalles de casas señoriales (aunque siguen dominando las fotos sobre monumentos y edificios religiosos), y hay gente en las pocas fotografías de playas que aparecen (mientras que, en $A T E$, las playas se encontraban desiertas).

Dejando al margen el dosier de 65 láminas añadido en NATE, las restantes fotografías incluidas en ambas obras son en blanco y negro y llevan unos pies eminentemente toponímicos en castellano y, en ocasiones, en francés, inglés y alemán. Por lo que respecta a $A T E$, la mayoría de ellas fueron realizadas por importantes fotógrafos del momento, entre los que destacan Kindel (nombre artístico de Joaquín del Palacio), con una aportación de 59 fotografías; Diego Quiroga Losada, Marqués de Santa María del Villar, con 36; S. de Kaskel, A. Zerkowitz, e Ilse Steinhoff, con 24 cada uno; Lladó, con 20; W. Conitz, con 18 fotografías; y O. Wunderlich y Andrada, con 16 fotografías cada uno. Entre las aportaciones procedentes de organismos institucionales o de estudios fotográficos especializados, figuran, además de las de la propia DGT (18 fotografías), las del Archivo Mas (21) y la Casa Lux (9). La nómina completa de autores asciende a 62 . Un total de 65 fotografías de NATE ya estaban contenidas $A T E$, aunque muchas de éstas son presentadas en un tamaño distinto. Los pies toponímicos de las fotografías solo están en castellano y en la reseña se traducen a los idiomas inglés, francés y alemán. Son 77 los fotógrafos de esta nueva edición, de entre los que destacan Kindel (de nuevo el más importante, en este caso con mucha diferencia, en cuanto al número de fotos aportadas, con 203, lo que supone cerca del $42 \%$ del total de la obra), R. González Ubierna (con 17), Paniagua (15), O. Wunderlich (12), el Marqués de Santa María del Villar (10), Foradada (10), Gillon (9), Serrano (9) y Lladó (8). En líneas generales, estos fotógrafos fueron contratados por los organismos oficiales de turismo de la época (PNT, SNT o DGT), si bien, con algunas excepciones (como Kindel o el Marqués de Santa María del Villar), su trabajo para tales organismos es menos conocido que el resto de su producción fotográfica (Vega, 2008-2009: 193; Sánchez, 2007; López, 1996).

En relación con esta cuestión, resulta interesante examinar qué instituciones oficiales encargaron las fotografías publicadas en ATE y NATE, así como la conexión de estas últimas con otro de los medios fundamentales en la iconografía turística de la época, como fue la cartelería. Sobre el primer asunto, la consulta de los fondos fotográficos históricos de la administración turística española, conservados en el AGA, arroja conclusiones significativas que prueban la continuidad, en este punto, de determinados imaginarios anteriores a la Guerra Civil. En efecto, una pequeña parte de las fotografías de ambas obras procede del requisado archivo del PNT, en cuyas oficinas, sitas en la madrileña calle Duque de Medinaceli, se estableció, tras el final de la Guerra, la sede de la DGT. De hecho, como se ha comentado en la semblanza biográfica de Rafael Calleja, al poco de terminar la contienda Luis Bolín pidió a éste que se trasladara desde San Sebastián a Madrid a fin de organizar la Sección de Propaganda y Publicaciones del SNT y revisar los archivos fotográficos del PNT, lo que explica fácilmente la reutilización de muchas de sus imágenes por parte de la propaganda turística del primer franquismo ${ }^{16}$. En concreto, un total de 19 fotografías de ATE y 7 de NATE (5 de

16 La totalidad de las fotografías procedentes del PNT ha sido agrupada recientemente por el AGA en el llamado Catálogo Monumental de España (1928-1936), que está digitalizado y se puede consultar a través del sitio web de este organismo. 
ellas ya reproducidas en la obra anterior) están contenidas en el Catálogo Monumental de España (1928-1936), por lo que sabemos que provienen de los fondos fotográficos del PNT. Por su parte, los servicios fotográficos propios de la DGT aportaron 17 fotografías a ATE, y el Servicio Fotográfico del Ministerio de Información y Turismo (SOMIT) contribuyó con 5 a NATE. El resto de las fotografías fueron realizadas por los fotógrafos mencionados, algunos de los cuales ya habían trabajado para el PNT. Las fechas en que se realizaron las fotografías contenidas en la parte fotográfica de ATE y NATE oscilan, por tanto, entre 1928 (año de creación del PNT) y 1957 (año de publicación de NATE).

Respecto a la segunda cuestión que apuntábamos anteriormente, resulta también significativa la conexión entre el material fotográfico de ATE y NATE y el cartelismo de la administración turística de la época. Los carteles turísticos fueron publicaciones frecuentes de la Sección de Propaganda y Publicaciones de la DGT, dirigida por Rafael Calleja. De hecho, todos los organismos oficiales de turismo, desde el PNT en adelante, han empleado el cartel como uno de los instrumentos principales de promoción (IET, 2005). Junto a los expedientes de publicación de NATE encontrados en el AGA, se localizan multitud de expedientes de carteles turísticos. La DGT publicó dos tipos de carteles durante el período de 1939-1959: los basados en el dibujo artístico coloreado (entre los cuales varios fueron diseñados por Serny, autor, como ya apuntamos, de las ilustraciones de los preámbulos de ATE y NATE) y los basados en fotografías en blanco y negro (terreno en el que destacará, entre otros, otro asiduo colaborador en las obras de Calleja, como fue Kindel). La cartelería de la DGT se alejó de la estética vanguardista y de la imagen de país moderno ofrecidas por el PNT y se centró en resaltar esa trilogía Arte-Historia-Naturaleza ensalzada, como hemos visto, por Calleja en el texto que cierra $A T E$ : la mayoría de los carteles de la DGT basados en fotografías muestran a tipos humanos ataviados con trajes típicos, así como paisajes naturales y humanizados tradicionales (con especial predilección por los ámbitos rurales y las ciudades históricas) y detalles de monumentos y casas típicas, de acuerdo con una estética y una orientación temática que coinciden claramente con las de las dos obras principales editadas por Calleja.

Por otra parte, ocho fotografías contenidas en el dosier fotográfico de ATE y cinco de NATE también fueron reproducidas en carteles turísticos publicados por la DGT entre 1944 y 1946 (en algunos casos reimpresos en años posteriores) ${ }^{17}$. Asimismo, cuatro láminas a color de NATE fueron publicadas previamente, desde 1950 en adelante, en carteles turísticos acompañados del eslogan «Spain is different» ${ }^{18}$, el cual, como ya vimos, no venía sino a incidir en algunos de los argumentos principales expuestos por Calleja en ATE. La conexión entre las dos obras señaladas y la famosa campaña de carteles impulsada por la DGT a partir de 1948 no solo fue, por tanto, un hecho evidente, sino que también conformó la base de una de las acciones propagandísticas de la administración turística del Estado que más recuerdan los españoles (IET, 2006: 42).

17 Se trata, en su mayoría, de carteles fotográficos pertenecientes a las series «Bellezas de España, «Visitez l'Espagne» y «Spain. Every type of art, every phase of nature» (IET, 2005).

18 En concreto, los carteles con fotografías de las casas colgadas de Cuenca (reproducida posteriormente en la lámina LVI de NATE); la fuente de Apolo, en el Paseo del Prado de Madrid (lámina LX de NATE); la calle del Agua, en el barrio de Santa Cruz, en Sevilla (lámina LXI de NATE), y un «rincón típico» de esta misma ciudad (que corresponde de hecho a los jardines del Alcázar, como se aclara en la explicación de la lámina XXV de NATE). Dichos carteles pueden visualizarse en el catálogo digital antes citado (http://www.iet.tourspain.es/), que los data aproximadamente en 1950 . 


\subsection{Fotografía, imagen de España e identidad nacional: paisajes, monumentos y tipos humanos}

Con su exaltación de los paisajes, monumentos y aspectos típicos de España y su propósito de identificar y dar a conocer las «singularidades exclusivas» por las que el país se diferenciaba del resto de Europa, las obras de Rafael Calleja ejemplifican bien el uso del discurso y de la propaganda turísticos al servicio, no sólo de los propósitos económicos y políticos del régimen de Franco (entre ellos, y como ya se había intentado años antes mediante las citadas Rutas de Guerra, ofrecer una imagen de normalidad que contribuyera a la aceptación de la dictadura en el exterior), sino también de sus concepciones nacionales. Este último hecho no era, por lo demás, novedoso, pues la propaganda turística oficial ha sido tradicionalmente uno de los principales medios a través de los cuales la administración ha reflejado y a la vez promovido sus ideas particulares sobre la identidad nacional. La influencia del turismo en la imagen de España y el papel desempeñado por la política y la administración turísticas en la construcción y promoción de una determinada idea de la identidad nacional, conforme a los regímenes y concepciones políticas prevalecientes en cada momento, han suscitado ya una amplia bibliografía, dentro de la cual cabe citar, por su esfuerzo sintético, trabajos como los de Afinoguénova (2007) y Storm (2013). En el caso de las obras de Calleja, como ya hemos visto, esa propaganda se efectúa sobre todo a través de la fotografía (en la línea de la cartelería editada coetáneamente por la DGT) y persigue fundamentalmente -como ya lo había hecho la Comisaría Regia del Turismo (Afinoguénova, 2007; Ortega, 2014)- atraer un turismo cultural y de élite capaz de valorar la riqueza y la diversidad regional del patrimonio paisajístico, folklórico e histórico-artístico del país.

Entre tales recursos, la importancia conferida al paisaje en estas obras, y en especial en $A T E$, merece ser destacada. De un lado, el paisaje, o su proverbial variedad interna, se presenta, desde el propio comienzo de ambas obras (al igual, según vimos, que a su conclusión), como la primera de esas «singularidades exclusivas» de España:

«Entre los países de Europa -comienza el preámbulo de Calleja-, destácase España por singularidades exclusivas. La primera, su paisaje. Un pueblo que vive en territorio donde se encuentran los montes de León o de Asturias y los valles de Lérida o los campos andaluces; la Costa Brava o los acantilados norteños y las suavidades femeninas de las Rías Bajas; las dehesas de Extremadura y la Huerta valenciana; Castilla, el Ampurdán y el Pirineo, Sierra Nevada y Aranjuez, los Picos de Europa y las campiñas vascas o las montañesas, tesoros naturales en que el prodigio iguala a la diversidad, ese pueblo bien puede jactarse de reunir, en espacio relativamente estrecho, la más rica y matizada variedad de los paisajes europeos» (Calleja, 1943: 7).

Esa variedad paisajística, de la que dan prueba fehaciente tanto la descripción literaria como la selección fotográfica de Calleja, ordenadas por regiones históricas, conforma además un recurso turístico esencial, que en algunas regiones deviene incluso el atractivo principal:

«Hablando de España, es indudable, por ejemplo, que en León, en Galicia, en la montaña, los respectivos habitantes pierden, turísticamente, personalidad ante lo que allí nos atrae y seduce: el paisaje» (Calleja, ibíd.: 25). 
De otro lado, el paisaje es exaltado también como vehículo fundamental de patriotismo, pues, al decir de Calleja:

«Lo mejor de España es la frecuencia y la diversidad de motivos que de Norte a Sur, de Levante a Occidente, se encuentran para sentir orgullo de ser español. ¡Rica, varia, multiforme España!» (Calleja, ibíd.: 45).

Junto al análisis textual, el análisis cualitativo y estadístico de las fotografías de ATE y NATE desde el punto de vista temático y geográfico arroja datos igualmente interesantes en relación con la imagen turística de España ofrecida por ambos libros. Desde el punto de vista temático, son tres, como ya se ha indicado, los motivos que componen el dosier fotográfico de las obras, y que, a su vez, sintetizan el tipo de recursos y atractivos turísticos que según el autor atesoraba y debía promocionar el país, a saber: pueblos y paisajes; monumentos y edificios emblemáticos; y escenas y tipos humanos. El propio subtítulo de ATE («Cuatrocientas treinta nueve fotografías de Paisajes, Monumentos y Aspectos típicos españoles») da idea de esta división temática. En este sentido, resulta significativo que las imágenes dedicadas a pueblos y paisajes conformen, de largo, la categoría más importante en ATE, con 270 fotos, que representan el $61,5 \%$ del total de las contenidas en la obra, frente al peso, sensiblemente menor, de las imágenes de monumentos (111 fotos, el 25,3\% del total) y de escenas y tipos humanos ( 57 fotos, $13 \%$ del total). En NATE, sin embargo, ciñéndonos al dosier fotográfico en blanco y negro (el principal en importancia, y el único que sigue una lógica similar a la de $A T E$ ), el conjunto de fotografías dedicadas a cada una de las tres temáticas señaladas es bastante homogéneo, y las imágenes referidas a escenas y tipos humanos (180 fotos, el 37,1\% del total de la obra) superan ligeramente en número a las de pueblos y paisajes (166 fotos, el $34,3 \%$ del total) y monumentos y edificios emblemáticos (138 fotos, el 28,5\% del total) (Figura 1).

Por otra parte, el análisis de las fotografías de ATE y NATE resulta significativo de las preferencias del autor por ciertas regiones históricas. Lo primero que cabe subrayar en ese sentido es que, como recoge la Figura 2, basada en el cómputo de las fotos de ambas obras, las regiones más representativas en las dos publicaciones son, claramente, Andalucía (a la que se refieren 57 fotos de ATE, que suponen el 15\% del total analizado; y 48 de NATE, el 15,8\% del total) y las dos Castillas (que, sumadas, centran el $22,6 \%$ de las fotos de ATE y el 30,6\% de las de NATE). Dentro del amplio conjunto regional castellano, cabe precisar que las imágenes referidas al ámbito de Castilla la Vieja (54 fotos, equivalentes al 14,2\% del total, en ATE; 51 fotos, 16,8\% del total, en NATE) ocupan un peso más relevante que las relativas a Castilla la Nueva (32 fotos, 8,4\% del total, en ATE; 42 fotos, 13,8\% del total, en NATE), región en la que se incluye Madrid; y, en la segunda de las obras estudiadas, superan incluso a Andalucía. Si a las fotos referidas a las provincias históricas de las dos Castillas sumamos además las de las provincias de la región histórica de León (León, Zamora y Salamanca), que son 21 en $A T E$ y 18 en NATE, la preponderancia del bloque castellano y leonés queda patente en los dos libros. 
Figura 1

NÚMERO DE FOTOS DE ATE Y NATE, CLASIFICADAS POR GRANDES

\section{BLOQUES TEMÁTICOS}

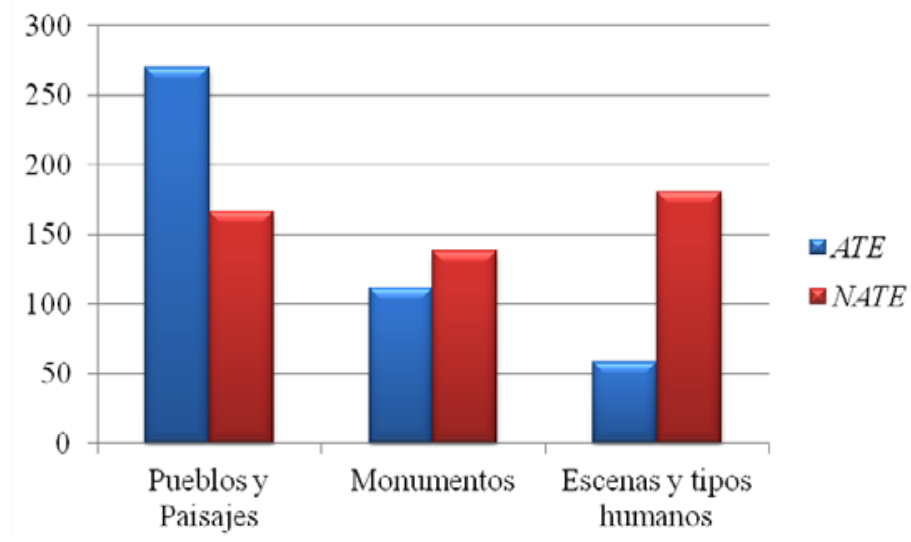

Fuente: elaboración propia.

Figura 2

NÚMERO DE FOTOS DE ATE Y NATE, CLASIFICADAS POR REGIONES HISTÓRICAS ${ }^{19}$

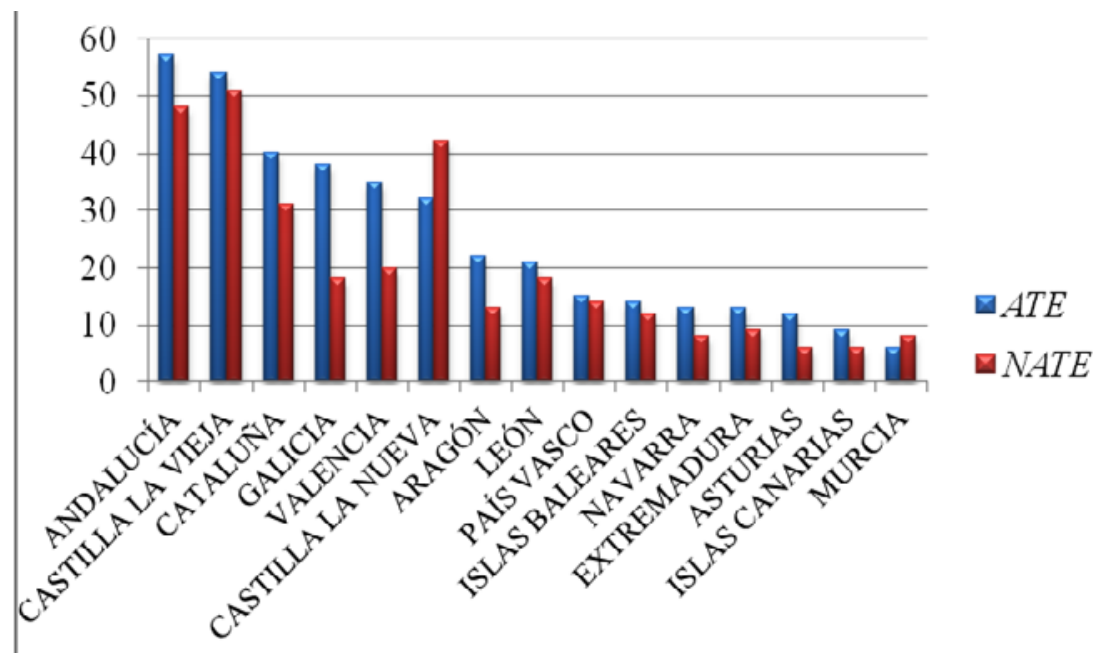

Fuente: elaboración propia.

19 Según la composición provincial de la división regional histórica seguida en el citado Real Decreto de 30 de noviembre de 1833 . 
El protagonismo iconográfico atribuido en las obras a Andalucía y las Castillas y León responde bien a la concepción de la diferencia española desarrollada por Calleja y, más ampliamente, por el discurso turístico del régimen: mientras que, según Calleja, «Andalucía es lo más conocido de España en el mundo, hasta ser para muchos extranjeros lo español por antonomasia» (Calleja, 1943: 29), Castilla ocupa un lugar muy destacado en el imaginario nacionalista del franquismo, definido, en buena medida, por el nacionalcatolicismo. La tesis historiográfica de una Castilla como «corazón» o «alma de España» y núcleo aglutinador de la unidad nacional, característica (aunque no original ni exclusiva, como es bien sabido) de este imaginario (Morales y Esteban, 2005; Mainer, 2013), tiene durante esta etapa su reflejo en un discurso turístico oficial que valora considerablemente los paisajes, el patrimonio histórico y el folklore de las ciudades y pueblos castellanos (Poutet, 1995). Así, aunque en el preámbulo de ambas obras les dedica poco espacio en comparación con otras provincias o regiones, resulta significativo que en su alabanza final Calleja se refiera a «todas las tierras y ciudades de Castilla y León» como «centros de nuestro escudo, museos de Historia y Arte, archivos y viveros de ardimiento e hidalguía» (Calleja, 1943: 44). Como también resultan significativas las coincidencias entre la iconografía de las obras de Calleja, con su interés por los paisajes y pueblos castellanos, y la de otras publicaciones de la época muy próximas a la administración turística del régimen, como la Revista Geográfica Española (1938-1977), fundada y dirigida hasta 1962 por Valeriano Salas (García Álvarez y Marías, 2011). De acuerdo con el discurso turístico oficial del primer franquismo, de las que las obras aquí analizadas resultan enormemente expresivas, en Andalucía y las Castillas se condensaría, pues, la diferencia española (Kelly, 2000: 30).

Muy por detrás de estas se situarían, en cuanto a su presencia en la iconografía de ambas obras, las demás regiones españolas, comenzando por Cataluña (con 40 fotos, el $10,5 \%$ del total, en ATE; y 31 fotos, el 10,2\% del total, en NATE), Galicia (30 fotos, 10\% del total, en ATE; 18 fotos, $6 \%$ del total, en NATE) y Valencia (35 fotos, 9,2\% del total, en ATE; 20 fotos, 6,6\% del total, en NATE), mientras que Navarra, Extremadura, Asturias, Canarias y Murcia concitan en ambas obras el menor número de fotos (Figura 2).

Por otra parte, atendiendo a la clasificación que hemos establecido para el análisis estadístico de las fotografías de pueblos y paisajes, es de resaltar que el tipo de paisaje más representado en las obras de Calleja es el paisaje urbano y rural-urbano (entendiendo este último como aquel referido a fotografías de localidades y pueblos de España enmarcados en su espacio rural circundante). A este tipo de paisaje se refieren el $57 \%$ de las fotos de temática paisajística publicadas en ATE, y el $47 \%$ de las reproducidas en NATE. Aunque Madrid recibe, como capital del Estado, una atención importante (siendo, junto con Sevilla, la ciudad más representada en el conjunto de ambas obras, con un total de 19 fotos), resultan significativas las numerosas fotografías dedicadas a las ciudades históricas (entre las cuales destacan, por su mayor presencia, Sevilla, con 19 imágenes; Santiago de Compostela, con 13; Segovia y Ronda, con 12; y Granada y Salamanca, con 10), escenarios ideales para mostrar los monumentos de un pasado que el discurso oficial del régimen percibía como glorioso. El hecho de que en la mayoría de las fotografías de temática paisajística, como en las que representan monumentos y edificios emblemáticos, no aparezcan figuras humanas (sólo el 31,7\% del total de fotos de ATE y el 44,3\% de 
las de NATE las incluyen) parece también revelador de la mirada turística adoptada y promovida por las obras de Calleja, así como por el cartelismo fotográfico de la DGT durante la época en que esta persona sirvió en ella. Dicha mirada coincide, grosso modo, con la caracterización que algunos autores (Gali y Donaire, 2003) han hecho de la imagen romántica de la ciudad: una concepción estética que mira el espacio turístico con actitud contemplativa y para consumo individual y que se centra en los cascos históricos y en el patrimonio monumental, y en especial eclesiástico.

Junto a las imágenes de tema urbano o rural-urbano, también son destacables los paisajes o motivos eminentemente naturales (incluyendo fotografías de fauna y flora), que suponen el 30\% del total de las fotos de tema paisajístico publicadas en ATE y el 43,4\% de las de NATE. Los paisajes naturales representados son variados, e incluyen ríos y valles fluviales, mesetas y llanuras sedimentarias, montañas, costas, etc., que ilustran bien la diversidad geográfica española, con inclusión de los archipiélagos canario y balear, sin que pueda afirmarse que los paisajes de playa, que van a ser protagonistas del modelo turístico español a partir del decenio de 1960, ocupen en las obras de Calleja un papel prevaleciente. Asimismo, las fotografías sobre paisajes eminentemente industriales son inexistentes en ambas obras, al igual que son escasas (en especial en ATE) las imágenes de espacios más específicamente modelados por el turismo y en general aquellas que muestran de manera explícita la presencia de turistas o visitantes.

Entre las fotografías dedicadas a monumentos y edificios emblemáticos, resulta significativo el predominio de las imágenes dedicadas a edificios religiosos (catedrales, iglesias y monasterios): 45 de los 80 monumentos fotografiados en ATE y 59 de los 119 que se representan en NATE son de este carácter. Igualmente lo es el peso de la arquitectura histórica de tipo militar (murallas, alcazabas y sobre todo castillos) en la iconografía de ambas obras (hay 15 monumentos de este tipo en cada una de ellas), mientras que, por el contrario, la arquitectura palaciega y de carácter civil (dentro de la que, aparte de los palacios y sitios reales, destacan las casas señoriales, los jardines y las fachadas de algunas universidades históricas) tiene escasa presencia en ATE (16 monumentos de este tipo) y mucho más significativa en NATE (40 monumentos). Esta valoración fotográfica del patrimonio eclesiástico y militar (y, dentro de este, de los castillos castellanos de origen medieval) probablemente tampoco resulte ajena a las concepciones nacional-católicas hegemónicas en el régimen de Franco (marcadas, entre otros rasgos, por la exaltación de los valores religiosos y castrenses), aunque los preámbulos de las dos obras analizadas carecen, bien es cierto, de cualquier declaración explícita en este sentido. Los monumentos y edificios emblemáticos más representados, considerando el conjunto de la ATE y NATE, son, por este orden, el Alcázar de Sevilla (8 fotografías), la Catedral de Santiago de Compostela (8), la Catedral de León (3), San Miguel de Lillo (3), el Museo del Prado (3), la Alhambra de Granada (3), la Catedral de Plasencia (3) y la Mezquita de Córdoba (3).

La apuesta del discurso turístico de la época por la exaltación de la diferencia española, apoyada en un patrimonio antiguo, variado y aparentemente inmune al progreso se refleja también, en las obras de Calleja, en la importancia otorgada a las fotografías de carácter costumbrista o tipista. Las imágenes que hemos clasificado en la categoría de escenas y tipos humanos suponen aproximadamente un $13 \%$ del total las fotografías publicadas en ATE y un $37 \%$ de las de NATE. Entre ellas, dominan claramente las imágenes referidas 
a actividades populares festivas de carácter tradicional (religiosas o no), con personas y grupos ataviados con trajes típicos locales o regionales, que suponen un $44 \%$ de las fotos de esta categoría temática en ATE, y un $51 \%$ en NATE. Con bastante menos peso que la temática anterior, se encuentran también fotografías de personas y grupos humanos representativos de oficios no religiosos o en actitud de trabajo, relacionados en su amplia mayoría con el sector primario, así como otras dedicadas a alimentos y platos gastronómicos típicos españoles. Finalmente, cabe reseñar que en ATE no hay ninguna fotografía relacionada con el ocio urbano moderno, que sí existen, en cambio, en NATE, donde aparecen, por ejemplo, escenas de fútbol, carreras de motos, regatas o simplemente personas en actitud de paseo.

\section{CONCLUSIONES}

Este artículo se ha detenido en el análisis de dos obras singulares que fueron concebidas y desarrolladas en el seno de la administración turística española del primer franquismo, tratando de destacar su relevancia y significación. Al mismo tiempo, ha pretendido estudiar y resaltar la importancia que en ella desempeñó una figura, Rafael Calleja, cuya faceta como publicista del turismo español durante casi treinta años ha pasado, hasta el momento, bastante inadvertida.

Las conclusiones principales de este trabajo pueden resumirse en cuatro. En primer lugar, la investigación aquí expuesta se ha aproximado a ambas obras como productos harto ilustrativos y representativos -si no canónicos- del discurso turístico oficial de la época (en muchos aspectos conectado, bien es cierto, con ideas e imágenes ya manejadas en otras etapas anteriores de la política turística española). Un discurso dirigido a minorías interesadas en los atractivos culturales del país y basado en dos pilares: el énfasis en la riqueza y variedad regional interna y la exaltación de la diferencia o excepcionalidad española con respecto a Europa, enmarcada esta última en los postulados del nacionalismo característico del régimen franquista.

En síntesis, el propósito de las obras de Rafael Calleja fue dar a conocer las «singularidades exclusivas» por las que España se diferenciaba del resto de los países europeos, a través de un recorrido tanto literario como fotográfico por sus distintas regiones y provincias. Aunque, según hemos visto y han resaltado anteriormente otros autores (en especial Pack, 2009: 114), no puede afirmarse de forma terminante que Rafael Calleja inventara el eslogan «Spain is different», fue muy probablemente el primero que lo fundamentó y desarrolló de manera explícita en una obra publicada por la administración turística española. Y en su calidad de jefe de la Sección de Propaganda y Publicaciones de la DGT contribuyó sin duda a convertirlo en un ingrediente central de la publicidad turística oficial casi dos décadas antes del inicio de boom turístico español y de la etapa de Manuel Fraga al frente del MIT, a la que erróneamente ha solido y suele todavía atribuirse, en la historiografía, la acuñación de dicho eslogan.

De hecho, y como es sabido, aunque el eslogan continuara vigente y se explotara con frecuencia durante la etapa del ministerio de Fraga, el discurso y, con éste, la propaganda y la iconografía oficiales del turismo español se renovaron y modernizaron considerablemente para adaptarse a la demanda (masiva y de «sol y playa») que, desde el decenio de 
1960, ha marcado, de manera hegemónica e indiscutida, la evolución de este sector (Vega, 2008-2009: 198 y ss.; Storm, 2013: 543 y ss.). Como bien ha resumido Vega, aunque el monumento, la historia y el arte, al igual que las tradiciones populares, «siguieron siendo activos seguros e irrenunciables» en las campañas impulsadas a partir de esta época por el MIT, la nueva iconografía vinculada a la propaganda oficial incorporó con fuerza la imagen de los espacios generados específicamente por la actividad turística, y en especial «la playa como instalación turística, preparada y habilitada para el turista que venía a disfrutar de España como 'país del sol'»(Vega, ibíd., 202). Los propios cambios introducidos en el preámbulo o en las fotografías de NATE respecto a ATE parecen anticipar la preocupación creciente de la administración franquista por fomentar una imagen más moderna del país y una oferta turística más diversificada y renovada, donde, junto a los reclamos tradicionales ya señalados, se da entrada a otros recursos, espacios y actividades, como los gastronómicos y los de carácter lúdico y deportivo.

En segundo lugar, no puede obviarse que una de las principales finalidades de ATE y NATE era servir de instrumentos propagandísticos eficaces, pues con este objetivo fueron concebidas por su autor (a la sazón jefe de la Sección de Propaganda y Publicaciones de la DGT), quien, además, contribuyó decididamente a lograr que las obras consiguieran publicarse. En relación con esta dimensión propagandística, el análisis aquí expuesto ha incidido en el papel desempeñado por la fotografía en el discurso turístico oficial del primer franquismo. Aunque el uso de la misma no era, ciertamente, novedoso dentro de la administración turística española, que la había aprovechado profusamente desde los tiempos de la Comisaría Regia, no es hasta fines de los años 1940 cuando la fotografía se convierte en un elemento dominante en la iconografía turística oficial, empezando por la cartelería. Las obras objeto de este artículo ejemplifican bien este protagonismo, y fueron posibles precisamente gracias al trabajo de un numeroso grupo de fotógrafos que trabajaron para la administración turística franquista, respondiendo, en palabras de Vega, a la demanda de ésta de «mostrar España como un catálogo de bellezas «complacientes» (Vega, ibid., 197.

En tercer lugar, el análisis estadístico, cuantitativo y cualitativo, de las fotografías de ATE y NATE, complementado con el de los preámbulos respectivos de ambas obras, permite poner de manifiesto el protagonismo iconográfico atribuido en ellas a ciertas regiones (Andalucía y las Castillas), paisajes (ciudades históricas, pueblos pintorescos), monumentos (entre los que destacan claramente los de naturaleza religiosa) y aspectos típicos (en especial fiestas populares), así como la preferencia por una determinada forma de relacionarse con el espacio turístico, entendido como una suerte de santuario natural o museo histórico-artístico («un relicario de Arte, Historia y Naturaleza», en palabras del propio Calleja) que el visitante podía, sobre todo, contemplar y admirar de manera íntima y personal. Como ha tratado de mostrarse aquí, dicho protagonismo, aparte de aprovechar la visión exótica y tipista de España construida por el romanticismo y centrada en el elemento andaluz, que ya era claramente hegemónica para el turismo procedente del exterior, refleja en buena medida la concepción de la diferencia española desarrollada por Calleja y, de manera más amplia, por el discurso turístico oficial del primer franquismo, estrechamente conectada a la propagación de los valores tradicionalistas del régimen y a su visión de la identidad nacional. En todo caso, conviene destacar 
que las obras de Calleja recogen y promueven una idea de España que, aun resaltando la importancia de Andalucía en la constitución de la diferencia española, señala y elogia la diversidad regional del país como uno de sus valores y reclamos turísticos más relevantes y distintivos.

Por último, no podemos de dejar de mencionar el considerable interés de las obras aquí analizadas en tanto en cuanto fuentes documentales valiosas, tanto a nivel cualitativo como cuantitativo, para el conocimiento de la España de la época. Si bien es cierto que la intención propagandística consustancial a ambos libros, como en general a la publicidad turística oficial, se traduce en una visión del país en buena medida sesgada e idealizada (en la que las catastróficas huellas materiales de la Guerra Civil o las difíciles condiciones de vida características de la postguerra desaparecen, obviamente, por completo), también lo es que los materiales fotográficos de ATE y NATE ofrecen un testimonio abundante y de calidad de cómo eran los paisajes, monumentos y tradiciones populares españoles en los años anteriores a las importantes trasformaciones iniciadas en el decenio de 1960, vinculadas al desarrollismo, que van a modificar rápida y drásticamente el país. El análisis de este conjunto fotográfico ofrece, así, un interés notable no sólo para la historia de la política turística en España, sino también para la historia y geografía histórica del paisaje, la historia del arte o la del patrimonio folklórico.

\section{BIBLIOGRAFÍA Y OTRAS FUENTES UTILIZADAS}

AFINOGUÉNOVA, E. (2007): «El discurso del turismo y la configuración de una identidad nacional para España», en Rey, A. del (Ed.), Cine, imaginario y turismo. Estrategias de seducción. Valencia, Tirant Lo Blanch, pp. 33-65.

AFINOGUÉNOVA, E. y MARTÍ-OLIVELLA, J. (2008): Spain is (Still) Different: Tourism and Discourse in Spanish Identity. Lanham, Lexington Books.

AGA: Archivo General de la Administración.

BERTHO-LAVENIR, C. (1999): La roue et le stylo: comment nous sommes devenus touristes. Paris, Editions Odile Jacob.

BOLÍN, L.A. (1967): Los años vitales. Madrid, Espasa Calpe.

CAlleJA, R. (1943): Apología turística de España. Madrid, Publicaciones de la Dirección General de Turismo.

CALlEJA, R. (1957): Nueva apología turística de España. Madrid, Publicaciones de la Dirección General de Turismo.

CALLEJA, R. (s.a.): Granada: 461 grabados, fotografías y dibujos. Bilbao, Publicaciones de la Dirección General de Turismo.

CORREYERO, B. y CAL, R. (2008): Turismo, la mayor propaganda del Estado. España: desde sus inicios hasta 1951. Madrid, Visión Libros.

DONAIRE, J.A. (2012): Turismo cultural. Entre la experiencia y el ritual. Bellcaire d'Empordà, Vitel.la.

FERNÁNDEZ ALMAGRO, M. (1958): «Rafael Calleja», $A B C$ de 24 de octubre de 1958, p. 9.

FERNÁNDEZ ALMAGRO, M. (1959): «Crítica y glosa: Nueva Apología Turística de España, por Rafael Calleja», $A B C$ de 25 de enero de 1959, p. 21. 
FERNÁNDEZ DE CÓRDOBA, E. (2006): Saturnino Calleja y su editorial. Los cuentos de Calleja y mucho más. Madrid, La Torre.

FUSI, J. P. (2000): España. La evolución de la identidad nacional. Madrid, Temas de Hoy.

GALÍ, N. y DONAIRE, J.A. (2003). «La imagen a priori de los destinos turísticos monumentales: el caso de Girona», Papers de Turisme, vol. 34, pp. 78-97.

GARCÍA ÁLVAREZ, J. (2007): «Paisajes nacionales, turismo y políticas de memoria: Toledo (1900-1950)», Ería, no 73-74, pp. 193-212.

GARCÍA ÁLVAREZ, J. (2009): «Lugares, paisajes y políticas de memoria: una lectura geográfica», Boletín de la Asociación de Geógrafos Españoles, n 51, pp. 175-202.

GARCÍA ÁLVAREZ, J. y MARÍAS, D. (2011): «Geografía, viajes y periodismo en la España del franquismo: Valeriano Salas y la Revista Geográfica Española». Scripta Nova. Revista Electrónica de Geografía y Ciencias Sociales. vol. XV, $\mathrm{n}^{\mathrm{0}} 378$, <http:// www.ub.es/geocrit/sn/sn-378.htm>.

GARCÍA ÁlVAREZ, J.; PUENTE P.; TRILLO, J.M. (2013): «La imagen de España en National Geographic Magazine (1888-1936)». Scripta Nova. Revista Electrónica de Geografía y Ciencias Sociales. [En línea]. Barcelona: Universidad de Barcelona, 20 de octubre de 2013, vol. XVII, no 454. <http://www.ub.es/geocrit/sn/sn-454.htm>.

HOLGUIN, S. (2005): "National Spain invites you': Battlefield tourism during the Spanish Civil War», American Historical Review, vol.110 (5), pp. 1399-1426.

INSTITUTO DE ESTUDIOS TURÍSTICOS (2005): Catálogo de carteles oficiales de turismo, 1929-1959. Madrid, IET.

INSTITUTO DE ESTUDIOS TURÍSTICOS (2006): La Administración Turística Española, Madrid, IET.

KELLY, D. (2000): «Selling Spanish 'otherness' since the 1960s», en Contemporary Spanish cultural studies. London, Arnold Publishers, pp. 29-37.

LOIS, R. et al. (2010): «La imagen del rural en la promoción turística de Galicia», Océanide, 2.

LÓPEZ, P. (1996): Las fuentes de la memoria III: fotografía y sociedad en la España de Franco. Barcelona, Lunwerg.

MAINER, J.C. (2013): «La imagen de Castilla en el fascismo español», en Morales, A., Fusi, J.P. y Blas, A. de (Dirs.): Historia de la nación y del nacionalismo español. Madrid, Galaxia Gutenberg, Fundación Ortega-Marañón, pp. 855-873.

MARTÍN, B. (2003): «La imagen de las regiones insulares: las islas como paraísos», Cuadernos de Turismo, $\mathrm{n}^{\circ}$ 11, pp. 127-137.

MARTÍNEZ DE PISÓN, E. (2012). Imagen del paisaje. La generación del 98 y Ortega y Gasset. Madrid, Fórcola.

MORALES, A. y ESTEBAN, M. (2005): ¿Alma de España? Castilla en las interpretaciones del pasado español. Madrid, Marcial Pons.

MORENO, A. (2007): Historia del turismo en España en el siglo XX. Madrid, Síntesis.

ORTEGA, N. (ed.) (2005) Paisaje, memoria histórica e identidad nacional. Madrid, Ediciones de la Universidad Autónoma de Madrid / Fundación Duques de Soria.

ORTEGA, N. (2014): «Paisaje, patrimonio e identidad en la conformación de la primera política turística española», Ería, nº 93, pp. 27-42. 
ORTEGA, N. y MARTÍNEZ DE PISÓN, E. (Eds.) (2009): El paisaje: valores e identidades, Madrid, Ediciones de la Universidad Autónoma de Madrid.

PACK, S. (2009): La invasión pacífica. Los turistas y la España de Franco. Madrid, Turner.

PELLEJERO, C. (2002): «La política turística en la España del siglo XX: Una visión general», Historia Contemporánea, $\mathrm{n}^{\circ} 25$, págs. 233-265.

POUTET, H. (1995): Images touristiques de L'Espagne: De la propagande politique a la promotion touristique. Paris, L'Harmattan.

ROBINSON, M. y PICARD, D. (Eds.) (2009): The Framed World. Tourism, tourists and photography. Farham, Ashgate.

ROMA, F. (2009): Turismo y paisaje. Una geografía de la representación turística. Madrid, Bubok.

RUIZ, J. et al. (2000): La Editorial Calleja, un agente de modernización educativa en la Restauración. Madrid, UNED.

SÁNCHEZ, J. M. (2007): Del daguerrotipo a la Instamatic. Autores, tendencias, instituciones. Gijón, Trea.

STORM, E. (2013): «Una España más española. La influencia del turismo en la imagen nacional», en Moreno, J. y Núñez, X.M., (Eds.), Ser Españoles. Imaginarios nacionalistas en el siglo XX. Barcelona, RBA, pp. 530-559.

VALLEJO, R. (2011): «Turismo y desarrollo económico en España durante el franquismo, 1939-1975», en X Congreso Internacional de la AEHE, 2011. Sevilla, UPO. Disponible en red: http://www.aehe.net/xcongreso/pdf/sesiones/turismo/turismo $\% 20 \mathrm{y} \% 20 \mathrm{des} a r r o-$ $110 \% 20$ economico $\% 20$ en $\% 20$ espana $\% 20$ durante $\% 20$ el $\% 20$ franquismo.pdf

VEGA, C. (2008-2009): «Fotografía y turismo en España. Políticas para una imagen de la diferencia», Estudis Balearics, no 94-95, pp. 193-206.

VEGA, C. (2011): Lógicas turísticas de la fotografía. Madrid, Cátedra.

WALTER, F. (2004): Les figures paysagères de la nation. Territoire et paysage en Europe (16e-20e siècle). Paris, Editions de 1'Ecole des Hautes Études en Sciences Sociales. 